\title{
Slow vital capacity
}

\author{
Shruti Singh', Sara Z. Khan', Bhakti Patel' ${ }^{2}$, Rammohan Gumpeni ${ }^{3}$, \\ Sameer Verma ${ }^{1}$, Arunabh Talwar ${ }^{1 *}$
}

\author{
${ }^{1}$ Department of Pulmonary, Critical Care and Sleep Medicine, Northwell Health, New Hyde Park, NY, USA \\ ${ }^{2}$ Stonybrook University, Stony Brook, New York, USA \\ ${ }^{3}$ Presbyterian Queens Hospital, Flushing, New York, USA
}

Received: 01 November 2020

Accepted: 11 December 2020

\author{
*Correspondence: \\ Dr. Arunabh Talwar, \\ E-mail: arunabhtalwar1@gmail.com
}

Copyright: (C) the author(s), publisher and licensee Medip Academy. This is an open-access article distributed under the terms of the Creative Commons Attribution Non-Commercial License, which permits unrestricted non-commercial use, distribution, and reproduction in any medium, provided the original work is properly cited.

\begin{abstract}
Forced vital capacity (FVC) and slow vital capacity (SVC) are non-invasive tests of respiratory function. Although FVC has been extensively studied and is used in most PFT (pulmonary function test) labs, SVC can also be used in clinical practice as it is a more comfortable and convenient test to perform. SVC-based diagnostic criteria can lead to earlier detection of obstructive lung disease. In contrast to FVC, SVC is less affected by respiratory muscle fatigue, airflow patency, expiratory muscle weakness and air leakage making it an appropriate test of respiratory function in patients of amyotrophic lateral sclerosis (ALS) and other neuromuscular disorders. As respiratory insufficiency is the major cause of mortality in ALS patients, regular SVC measurement provides the respiratory functional status, so that early treatment can be started which improves the survival and quality of life in these patients. The purpose of this article is to highlight the importance of considering SVC in clinical practice.
\end{abstract}

Keywords: Forced vital capacity, Slow vital capacity, Amyotrophic lateral sclerosis, Obstructive lung disease, Pulmonary function test

\section{INTRODUCTION}

Pulmonary function tests (PFTs) is a series of non-invasive tests to assess the lung function. ${ }^{1}$ Spirometry and lung volume measurements help the clinicians to diagnose the underlying obstructive or restrictive process, estimate the severity of lung diseases and help plan a treatment response. ${ }^{1,2}$ Interpretation of PFTs is done by comparisons of data obtained in patients with the reference values from healthy subjects with the same anthropometric variables like age, height, gender and ethnicity. ${ }^{1}$

Vital capacity can be measured as FVC, or as SVC both of which are important components of PFTs. FVC is defined as the expiratory volume delivered during an expiration cycle made as forcefully and as completely as possible starting from full inspiration. The SVC can either be measured during a slow, gentle, maximal expiration after a maximal inspiration or alternatively, during a maximal inspiration following a slow, gentle, maximal expiration. ${ }^{2-}$ 5 While performing a PFT both the FVC and SVC maneuvers are repeated for a minimum of three times and not more than eight times. In healthy individuals if performed correctly, the SVC should typically be equal to FVC due to the lack of dynamic compression on the

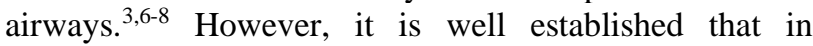
obstructive airways disease there may be a difference between FVC and SVC in the presence of increased collapsibility/compressibility of the airways. ${ }^{3,9,10}$

In patients with obstructive lung disease, SVC is greater than FVC because airway closure occurs earlier at a higher volume than the true residual volume (RV). This is due to the inflammatory narrowing of the peripheral airways and also during the forced maneuver of FVC, the dynamic compression of the airways further worsens the airway closure, resulting in air trapping with a higher RV and hence lower FVC. On the other hand, during the relaxed 
maneuvers of SVC, the airway closure is delayed due to little dynamic compression of the airways and low intrathoracic pressure resulting in a lower RV and higher SVC

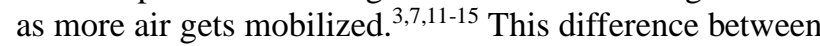
SVC and FVC has been referred to as an index of small airways collapse and increases further when more airways obstruction is present and the disease is more severe. . $^{3,6,12}$ Other authors have applied the ratio between FVC to SVC as an indicator of small airways collapse and air trapping. ${ }^{6}$

Clinically, obstructive airways disease is diagnosed when an obstructive ventilatory defect is present in the pulmonary function test. Obstruction is defined as the ratio of $\mathrm{FEV}_{1}$ to vital capacity below the lower limit of normal. A potential issue complicating this diagnostic approach is that vital capacity can be measured in various ways as FVC or SVC. In the event of a significant difference between SVC and FVC as seen in obstructed patients, one can potentially encounter a clinical scenario of a 'pseudonormal' $\mathrm{FEV}_{1} / \mathrm{FVC}$ ratio while the $\mathrm{FEV}_{1} / \mathrm{SVC}$ ratio may be below the lower limit of normal. For these reasons, the American thoracic society and the European respiratory society (ATS/ERS) recommends the use of the largest VC to calculate the $\mathrm{FEV}_{1} / \mathrm{VC}$ ratio (Tiffineau index) to define the obstructive airways disease. ${ }^{1}$

The differences between FVC and SVC are affected by variables like body mass index (BMI), age and gender. ${ }^{16}$ Fortis et al studied the effect of BMI on the difference between FVC and SVC by retrospectively reviewing the PFTs of 1805 subjects. The results showed that in the patients with a normal BMI $\left(\mathrm{BMI}<25 \mathrm{~kg} / \mathrm{m}^{2)}\right.$ with no obstruction, FVC was larger than SVC whereas in overweight and obese patients, the SVC was significantly larger than FVC and the SVC-FVC difference positively correlated with the BMI. Hence, the use of $\mathrm{FEV}_{1} / \mathrm{FVC}$ ratio would underdiagnose obstructive airway disease in obese patients. ${ }^{10}$

It is also suggested the FVC decreases with age at a faster rate than SVC and that a low $\mathrm{FEV}_{1} / \mathrm{SVC}$ ratio might simply reflect the physiological changes of aging. ${ }^{13}$ Mathieu Saint-Pierre et al. have shown that $\mathrm{FEV}_{1} / \mathrm{SVC}$ should be used with caution in elderly subjects [age $>70$ years] with preserved $\mathrm{FEV}_{1} / \mathrm{FVC}$ because a low value may represent a false positive finding for air flow obstruction. ${ }^{9}$ The FVC decreases with age due to the reduced chest wall compliance and expiratory muscle strength and a greater tendency of smaller airways to close during the forced maneuver. ${ }^{17}$ During SVC maneuver the smaller airways remain patent longer during the expiratory maneuver and hence the noticed difference between SVC and FVC increases with aging.

Although both FVC and SVC decay in a similar manner, both are non-invasive and interchangeable but SVC is a more comfortable and convenient test to perform in clinical practice because it is not largely affected by the respiratory muscle fatigue, airflow patency, expiratory muscle weakness and air leakage, in contrast to FVC measurement making SVC an appropriate measure of respiratory function. ${ }^{18-20}$ It is particularly easier to perform in patients with upper motor neuron disease or severe respiratory insufficiency like amyotrophic lateral sclerosis (ALS). ${ }^{20}$ FVC is particularly challenging to perform in ALS patients as it requires greater effort and coordination than SVC measurement leading to air volume leakage between the mouthpiece and the weak lips. ${ }^{20,21}$ FVC measurement is difficult in patients with severe bulbar disease as the upper airway collapses when maximal force is exerted during FVC. $^{20}$ SVC can be used for measurements over a long period of time to evaluate ALS disease progression. ${ }^{20}$ In addition, SVC is also convenient to perform in patients with severe airways obstruction who cannot generate a prolonged expiratory effort as it may lead to coughing and syncope. ${ }^{3}$

Due to the time and operational constraints, most pulmonary function testing laboratories still perform only the FVC maneuver. Also, most clinicians only use FVC while interpreting the pulmonary function tests. The purpose of this review is to highlight the clinical scenarios where considering and using SVC may be helpful in practical management of patients.

\section{SLOW VITAL CAPACITY IN NEUROMUSCULAR DISORDERS LIKE AMYOTROPHIC LATERAL SCLEROSIS}

Patients with progressive neuromuscular disorders particularly with bulbar involvement may not be able to perform FVC maneuver and in that setting, SVC may serve as an alternative measure of vital capacity. Amyotrophic lateral sclerosis (ALS) is a neuromuscular disease that causes progressive irreversible weakness of all skeletal muscles including respiratory muscles. ${ }^{22}$ Respiratory complications are a major determinant of disease progression and survival in the patients of ALS. Progressive weakness of respiratory muscles in ALS contributes to the dyspnea, orthopnea, sleep abnormalities, weak cough reflex and frequent respiratory infections. ${ }^{23,24}$ This respiratory insufficiency (RI) is the major cause of mortality in patients of ALS. $5,18,23,25$ Respiratory insufficiency usually develops late in ALS but occasionally can be the presenting feature. ${ }^{26}$ Hence regular assessment of the respiratory function is required in these patients so that early treatment can be started in the form of non-invasive ventilation. ${ }^{27-29}$ Measuring FVC and SVC using spirometry are frequently used to predict prognosis, survival, functional decline and hypercapnia in ALS patients. ${ }^{30-33}$

Forced vital capacity has been well studied in ALS and can help detect hypoventilation in amyotrophic lateral sclerosis and diaphragmatic weakness in supine position. It can also be used to monitor the progression of disease..$^{23,30,34-36}$ It has been suggested that the respiratory evaluation should be performed at the first visit and then every three months thereafter. ${ }^{29}$ 
Table 1: Studies of the role of SVC and FVC in ALS.

\begin{tabular}{|c|c|c|}
\hline $\begin{array}{l}\text { Author/year/study } \\
\text { type/dataset }\end{array}$ & Results & Conclusions \\
\hline $\begin{array}{l}- \text { Jackson et al } / 2018^{5} \\
-453 \text { placebo treated } \\
\text { ALS patients }\end{array}$ & $\begin{array}{l}\% \text { predicted SVC showed significant correlations } \\
\text { with dyspnea, orthopnea, respiratory insufficiency, } \\
\text { respiratory subdomain score, and total ALSFRS-R } \\
\text { score (all p }<0.0001 \text { ) }\end{array}$ & $\begin{array}{l}\text { Correlation between \% predicted } \\
\text { SVC and specific ALSFRS-R } \\
\text { symptom scores in ALS patients } \\
\text { with rapidly versus more slowly } \\
\text { progressing disease reinforces the } \\
\text { importance of continually } \\
\text { monitoring respiratory function }\end{array}$ \\
\hline $\begin{array}{l}\text {-Pinto et al/2017 }{ }^{18} \\
\text { Retrospective study } \\
-469 \text { ALS patients, } 270 \\
\text { males, with } 329 \text { spinal- } \\
\text { onset and } 140 \text { bulbar-on } \\
\text { set }\end{array}$ & $\begin{array}{l}\text { FVC and SVC were strongly correlated ( } \mathrm{p}<0.001) \\
\text { Both were strongly correlated with MIP and MEP } \\
\text { and moderately correlated with R-sub score for the } \\
\text { all population and spinal-onset patients } \\
\text { Both were weakly correlated for bulbar-onset } \\
\text { patients. }\end{array}$ & $\begin{array}{l}\text { FVC and SVC are interchangeable } \\
\text { in predicting survival in ALS }\end{array}$ \\
\hline $\begin{array}{l}\text {-Czaplinski et al/2006 } \\
\text {-1034 patients with } \\
\text { definite or probable } \\
\text { ALS }\end{array}$ & $\begin{array}{l}\text { The median survival of ALS patients with baseline } \\
\text { FVC }<75 \% \text { was } 2.91 \text { years, compared with } 4.08 \text { years } \\
\text { for patients with baseline FVC }>75 \% \text { ( } p<0.001 \text { ). } \\
\text { Patients with baseline FVC }<75 \% \text { progressed more } \\
\text { rapidly (taking } 8.0 \text { months to progress } 20 \text { AALS } \\
\text { points) compared with patients with baseline } \\
\text { FVC }>75 \% \text { (10.0 months, } p<0.001 \text { ) }\end{array}$ & $\begin{array}{l}\text { FVC value obtained at an initial } \\
\text { visit may serve as a clinically } \\
\text { meaningful predictor of survival } \\
\text { and disease progression in ALS }\end{array}$ \\
\hline $\begin{array}{l}\text {-Lechtzin et al/2002 } \\
-25 \text { ALS patients }\end{array}$ & $\begin{array}{l}\text { Upright FVC, } \mathrm{FEV}_{1} \text {, and MEP were all significantly } \\
\text { correlated with transdiaphragmatic pressure (Pdi), } \\
\text { while MIP and } \mathrm{PaCO}_{2} \text { were not, Supine } \mathrm{FVC} \text { was the } \\
\text { most highly correlated predictor of Pdi, supine FVC } \\
\text { of }<5 \% \text { predicted was } 100 \% \text { sensitive and specific for } \\
\text { predicting an abnormally low Pdi. Accessory muscle } \\
\text { use and abdominal paradox were both significantly } \\
\text { associated with Pdi, }\end{array}$ & $\begin{array}{l}\text { Supine FVC is an excellent and } \\
\text { simple test of diaphragmatic } \\
\text { weakness in ALS patients. }\end{array}$ \\
\hline $\begin{array}{l}- \text { Pinto et al/2019 } \\
-232 \text { ALS patients, } 134 \\
\text { men } \\
\text { 166 spinal and } 66 \\
\text { bulbar on set }\end{array}$ & $\begin{array}{l}\text { All variables declined significantly between the two } \\
\text { evaluations }(p<0.001) \text {, FVC and SVC were strongly } \\
\text { correlated }(p<0.001) \text { and FVC and SVC decays } \\
\text { between first evaluation and } 6 \text { months after were the } \\
\text { only significant prognostic variables }\end{array}$ & $\begin{array}{l}\text { FVC and SVC decay are inter- } \\
\text { changeable in predicting functional } \\
\text { decay in ALS. }\end{array}$ \\
\hline $\begin{array}{l}\text {-Andrews et al/2018 } \\
\text { Retrospective study } \\
\\
-893 \text { placebo treated } \\
\text { ALS patients, } 585 \\
\text { males, } 183 \text { with bulbar- } \\
\text { onset ALS }\end{array}$ & $\begin{array}{l}\text { Rate of decline of SVC was slower by } 1.5 \text { percentage } \\
\text { points per month in the first } 6 \text { months, risk } \\
\text { reductions for events after } 6 \text { months were } 19 \% \text { for } \\
\text { decline in the ALSFRS-R respiratory subdomain or } \\
\text { death after } 6 \text { months, } 22 \% \text { for first onset of } \\
\text { respiratory insufficiency or death after } 6 \text { months, } \\
23 \% \text { for first occurrence of tracheostomy or death } \\
\text { after } 6 \text { months, and } 23 \% \text { for death at any time after } 6 \\
\text { months (p<0.001 for all) }\end{array}$ & $\begin{array}{l}\text { The rate of decline in SVC is } \\
\text { associated with meaningful clinical } \\
\text { events in ALS, including } \\
\text { respiratory failure, tracheostomy, } \\
\text { or death, showing that it is an } \\
\text { important indicator of clinical } \\
\text { progression }\end{array}$ \\
\hline
\end{tabular}

ALS-Amyotrophic lateral sclerosis, ALSFRS-R-ALS functional rating scale revised, SVC-Slow vital capacity, FVC-Functional vital capacity, MIP-Mean inspiratory pressure, MEP-Mean expiratory pressure.

Similarly, SVC has also been studied in amyotrophic lateral sclerosis patients and Jackson et al showed that there exists a significant correlation between percentage predicted SVC and the symptoms of dyspnea, orthopnea, respiratory insufficiency, respiratory subdomain score and total ALSFRS-R score (ALS functional rating scale). ${ }^{5}$ It has been suggested that, SVC measurement can be a good 
predictor of disease progression and survival in ALS. ${ }^{18,37-}$

Pinto et al. also found that FVC and SVC are independent predictors of survival in ALS and bear a strong correlation. They stated that there is a 1.02 times increased probability of death for each $1 \%$ decline in the percentage of predicted value of FVC and SVC. ${ }^{18,19}$ Studies showing the role of SVC and FVC in ALS are summarized in Table 1. SVC has also been studied in other progressive neuromuscular disorders like RYR1-RM and has been found to be helpful in gauging patients' respiratory function particularly in conditions where respiratory muscle weakness results in respiratory insufficiency which places individuals at risk for early mortality. ${ }^{40}$

\section{SLOW VITAL CAPACITY IN OBSTRUCTIVE LUNG DISEASE}

Spirometry remains the cornerstone for the diagnosis of airways disorder and improving its diagnostic yield is important. According to the ATS/ERS, the ratio between $\mathrm{FEV}_{1}$ and maximal vital capacity (either FVC or SVC), as measured by spirometry, can be used to determine the presence of airway obstruction. ${ }^{1}$ As mentioned above in healthy individuals, the difference between SVC and FVC (SVC-FVC) is negligible. However, in the presence of airflow obstruction these differences can be apparent and are mostly related to the presence of underlying hyperinflation. Thus, using $\mathrm{FEV}_{1} / \mathrm{SVC}$ ratio can help detect the presence of airway obstruction in more individuals than the $\mathrm{FEV}_{1} / \mathrm{FVC}$ ratio, given that the vital capacity volume obtained by an SVC maneuver is greater than that obtained by an FVC maneuver.

Huprikar et al performed a retrospective analysis of 2710 PFTs of 2244 subjects from 2011 to 2015. Using the $\mathrm{FEV}_{1} / \mathrm{SVC}$ criteria, the prevalence of obstruction increased from 26.1 to $45 \%$ and 566 additional cases of obstruction were diagnosed who otherwise had a preserved $\mathrm{FEV}_{1} / \mathrm{FVC}$ showing that SVC-based diagnostic criteria can lead to earlier detection of disease with improved clinical outcomes. ${ }^{16}$

Saint-Pierre et al studied the PFTs of 13,893 adult patients with a $\mathrm{FEV}_{1} / \mathrm{FVC}$ and TLC at or above the lower limit of normal. It showed that performing the slow maneuver of SVC was able to uncover the airflow limitation which was missed by $\mathrm{FEV}_{1} / \mathrm{FVC}$. This was particularly true for younger obese patients with a normal $\mathrm{FEV}_{1} / \mathrm{FVC}$. The authors do emphasize that $\mathrm{FEV}_{1} / \mathrm{SVC}$ as a marker of airflow obstruction and it should be used with caution in elderly individuals (age $>70$ years) as it can give false positive results of airway obstruction in those subjects with preserved $\mathrm{FEV}_{1} / \mathrm{FVC}^{9}{ }^{9}$ This outcome is probably a consequence of aging. As with increasing age there is an increase in the SVC-FVC difference due to the increased airways collapsibility and senile emphysema of the aged lung leading to greater underestimation of vital capacity by FVC maneuver. ${ }^{41}$ Thus clinicians should consider the fact that in elderly population low. $\mathrm{FEV}_{1} / \mathrm{SVC}$ but preserved $\mathrm{FEV}_{1} / \mathrm{FVC}$ may just reflect the physiological effects of aging. Hence in elderly subjects the utility of using $\mathrm{FEV}_{1} / \mathrm{SVC}$ as a marker of obstruction is limited and using it to diagnose airways obstruction in that population carries the risk of over diagnosing airflow limitation.

In a study by Chhabra, 60 asthmatics and 20 normal patients performed spirometry maneuvers for measurement of FVC and SVC. These values were similar in normal patients but SVC was found to be significantly greater than FVC in moderate to severe asthmatics. The difference increased with increase in the degree of obstruction and the authors suggested that it is an indicator of air trapping. ${ }^{3}$

Likewise, Constan et al showed that there is difference between the SVC and FVC values in patients with obstructive disease due to the dynamic compression of the airway during the forced maneuver that causes early closure of the airway, increasing the residual volume and decreasing the FVC. Again, reinforcing the fact that using $\mathrm{FEV}_{1} / \mathrm{FVC}$ rather than $\mathrm{FEV}_{1} / \mathrm{SVC}$ may lead to under diagnosis of obstruction. The greater the difference between SVC and FVC, the greater is the severity of obstruction, air trapping and hyperinflation. ${ }^{12,42,43}$

In addition, to the SVC-FVC difference, the FVC/SVC ratio is also a sign of small airways collapse and air trapping in obstructive lung disease. ${ }^{6,44,45}$ Cohen et al studied the role of FVC/SVC ratio in the diagnosis of small airways obstruction in lung transplant patients with bronchiolitis obliterans (BOS). The study included 39 patients with BOS and 36 patients without BOS. The $\mathrm{FVC/SVC}$ ratio decreased significantly in BOS stages 1 and 2 by $2.2 \%$ and $4.4 \%$, respectively thereby suggesting that FVC/SVC could be used as a marker of small airways obstruction. It was concluded that decrease in FVC/SVC ratio reflects the small airways obstruction. ${ }^{6}$

Yuan et al studied the PFTs and cardiopulmonary exercise responses in 97 COPD patients to study the effect of SVC and FVC difference on the exercise capacity of these patients. It was observed that there was a significant difference between SVC and FVC and the larger this difference, the greater was the severity of airflow limitation and higher was the impairment of exercise performance in these patients. ${ }^{44}$

Barros et al performed a retrospective cross-sectional study on 1084 subjects to determine the importance of SVC in the detection of obstructive airway disease. The patients underwent spirometry and plethysmography to determine the $\mathrm{FEV}_{1} / \mathrm{FVC}$ and $\mathrm{FEV}_{1} / \mathrm{SVC}$ measurements. $\mathrm{FEV}_{1} / \mathrm{FVC}$ detected airway obstruction in $52.2 \%$ of the sample as compared to $43.9 \%$ cases by the $\mathrm{FEV}_{1} / \mathrm{SVC}$ ratio. Hence, $\mathrm{FEV}_{1} / \mathrm{SVC}$ were found to be more reliable than $\mathrm{FEV}_{1} / \mathrm{FVC}$ ratios in the early detection of obstructive disease. ${ }^{7}$ Similarly, in a study by Berton et al on 13,893 adult middle-aged females complaining of shortness of 
breath with $\mathrm{FEV}_{1}>70 \%$, BMI $>30 \mathrm{~kg} / \mathrm{m}^{2}$ and preserved $\mathrm{FEV}_{1} / \mathrm{FVC}$ ratios, it was found that $\mathrm{FEV}_{1} / \mathrm{SVC}$ ratio was smaller in patients with obstructive disease thereby diagnosing airflow limitation missed by the preserved $\mathrm{FEV}_{1} / \mathrm{FVC}$ ratio. The positive response of these patients towards inhaled albuterol treatment further proved the presence of obstructive ventilatory defect. ${ }^{13}$ Similar results have been reported by others as well. ${ }^{46-49}$ Studies showing the role of SVC and FVC in obstructive lung disease are summarized in Table 2.

Table 2: Studies of the role of SVC and FVC in obstructive lung disease.

\begin{tabular}{|c|c|c|}
\hline $\begin{array}{l}\text { Author/year/study } \\
\text { type/dataset }\end{array}$ & Results & Conclusions \\
\hline $\begin{array}{l}\text { Huprikar et al/2019 } \\
\text { Retrospective } \\
\text { study } \\
-2,710 \text { studies with } \\
2,244 \text { obstructive } \\
\text { lung disease subjects } \\
\text { were reviewed }\end{array}$ & $\begin{array}{l}\text { Obstruction was identified by spirometry in } 26.1 \% \\
\text { of the studies. With } \mathrm{FEV}_{1} / \mathrm{SVC} \text {, the prevalence of } \\
\text { obstruction increased from } 26.1 \text { to } 45.0 \% \text { and } \\
\text { identified } 566 \text { additional obstructive lung disease } \\
\text { patients. } \\
54 \% \text { of the subjects with newly identified } \\
\text { obstructive lung disease had smoking histories, } \\
\text { and } 67.4 \% \text { received medications for obstructive } \\
\text { lung disease. }\end{array}$ & $\begin{array}{l}\text { Use of FVC-based criteria alone did not } \\
\text { identify patients with obstructive lung } \\
\text { disease. SVC-FVC measurements in } \\
\text { these subjects will improve testing and } \\
\text { diagnosis of airflow limitation }\end{array}$ \\
\hline $\begin{array}{l}\text {-Saint-Pierre et } \\
\text { al/2019 } \\
\\
-13,893 \\
\text { Obstructive lung } \\
\text { disease } \\
\text { patients }\end{array}$ & 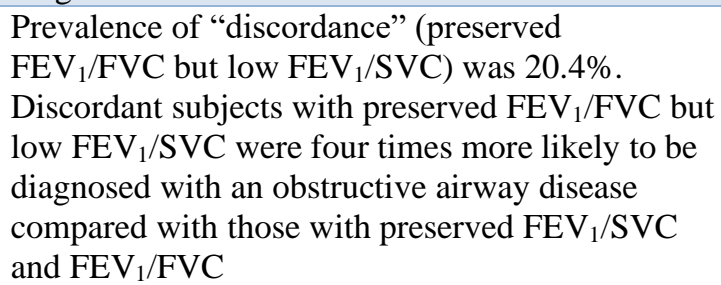 & $\begin{array}{l}\text { Using SVC instead of FVC in the } \\
\mathrm{FEV}_{1} / \mathrm{VC} \text { ratio enhances the yield of } \\
\text { spirometry in detecting obstructive lung } \\
\text { disease in younger and obese subjects. } \\
\text { But } \mathrm{FEV}_{1} / \mathrm{SVC} \text { ratio, should be used } \\
\text { with caution in elderly subjects }\end{array}$ \\
\hline $\begin{array}{l}- \text { Chhabra } / 1998^{3} \\
-60 \text { asthmatic patients } \\
\text { and } 20 \text { normal } \\
\text { patients }\end{array}$ & $\begin{array}{l}\text { The values were similar in normal patients but } \\
\text { SVC and IVC were significantly greater than FVC } \\
\text { in moderate to severe asthmatics. } \mathrm{FEV}_{1} / \mathrm{FVC} \text { ratio } \\
\text { was significantly different than } \mathrm{FEV}_{1} / \mathrm{SVC} \text { and } \\
\mathrm{FEV}_{1} / \mathrm{IVC} \text { measurements in moderate to severe } \\
\text { asthmatics }\end{array}$ & $\begin{array}{l}\text { The difference between SVC and FVC } \\
\text { increases with increase in the degree of } \\
\text { obstruction and is an indicator of } \\
\text { variable amount of air trapping showing } \\
\text { that } \mathrm{FEV}_{1} / \mathrm{SVC} \text { is a truer index of } \\
\text { airflow obstruction than } \mathrm{FEV}_{1} / \mathrm{FVC} \text {. } \\
\text { FVC underestimates the actual vital } \\
\text { capacity in these patients }\end{array}$ \\
\hline $\begin{array}{l}\text {-Barros et al/2013 } \\
\text { Retrospective cross- } \\
\text { sectional study } \\
\text {-1,084 Obstructive } \\
\text { lung disease patients }\end{array}$ & $\begin{array}{l}\text { The analysis of the } \mathrm{FEV}_{1} / \mathrm{FVC} \text { ratio revealed the } \\
\text { presence of airway obstruction in } 476 \text { individuals } \\
(43.9 \%) \text {, compared with } 566 \text { individuals }(52.2 \%) \\
\text { for the analysis of the } \mathrm{FEV}_{1} / \mathrm{SVC} \text { ratio. In the } \\
\text { airway obstruction, airway obstruction plus lung } \\
\text { hyperinflation, and mixed pattern groups, the } \\
\text { SVC-FVC was statistically superior to that in the } \\
\text { normal pulmonary function, reduced FEF, and } \\
\text { restrictive lung disease groups }\end{array}$ & $\begin{array}{l}\text { The } \mathrm{FEV}_{1} / \mathrm{SVC} \text { ratio detected the } \\
\text { presence of airway obstruction in more } \\
\text { individuals than the } \mathrm{FEV}_{1} / \mathrm{FVC} \text { ratio. } \\
\mathrm{FEV}_{1} / \mathrm{SVC} \text { ratio is more reliable than is } \\
\text { the } \mathrm{FEV}_{1} / \mathrm{FVC} \text { ratio in the detection of } \\
\text { obstructive pulmonary disease }\end{array}$ \\
\hline $\begin{array}{l}\text {-Constan et al/2005 } \\
\text {-162 individuals with } \\
\text { suspected airflow } \\
\text { obstruction }\end{array}$ & $\begin{array}{l}38 \text { patients were non-obstructive, } 53 \text { presented } \\
\text { with mild obstruction, } 39 \text { moderate and } 32 \text { severe } \\
\text { obstruction. The FVC was a } 3,1 \% \text { lower than the } \\
\text { EVC in non-obstructive individuals, a } 5,1 \% \text { lower } \\
\text { in those with mild obstruction, } 10 \% \text { lower in the } \\
\text { moderate obstructive and a } 16,8 \% \text { lower in the } \\
\text { severe obstructive groups }\end{array}$ & $\begin{array}{l}\text { The difference between the FVC and the } \\
\text { EVC increases with the degree of } \\
\text { obstruction. Hyperinflation in patients } \\
\text { with airway obstruction is determined } \\
\text { by the degree of obstruction }\left(\mathrm{FEV}_{1}\right) \text { and } \\
\text { by SVC-FVC }\end{array}$ \\
\hline $\begin{array}{l}-39 \text { patients }(26 \text { men }) \\
\text { with BOS after lung } \\
\text { transplantation } \\
\text { and } 36(14 \text { men }) \\
\text { bilateral lung } \\
\text { transplant recipients } \\
\text { without BOS }\end{array}$ & $\begin{array}{l}\text { The FVC/SVC ratio decreased significantly } \\
\text { during follow-up in patients with BOS stages } 1 \\
\text { and } 2 \text {, by } 2.2 \% \text { and } 4.4 \% \text {, respectively, from } \\
\text { baseline }(\mathrm{p}<0.001) \text {. This decrease was not } \\
\text { significantly associated with the decrease in } \\
\text { FEV } \text { The FVC/SVC ratio increased in the group }_{\text {without BOS by } 1.1 \%}\end{array}$ & $\begin{array}{l}\text { Decrease in FVC/SVC ratio is able to } \\
\text { detect small airway changes and } \\
\text { quantify small airways dysfunction like } \\
\text { BOS }\end{array}$ \\
\hline
\end{tabular}




\begin{tabular}{|c|c|c|}
\hline $\begin{array}{l}\text { Author/year/study } \\
\text { type/dataset }\end{array}$ & Results & Conclusions \\
\hline $\begin{array}{l}\text {-Yuan et al/201444 } \\
\text {-97 COPD patients }\end{array}$ & $\begin{array}{l}\text { Patients with } \mathrm{VC}>\mathrm{FVC} \text { had lower } \mathrm{FEV}_{1} \text { and peak } \\
\text { oxygen uptake }(\mathrm{VO} / \mathrm{kg}) \text { compared with patients } \\
\text { with } \mathrm{VC} \leq \mathrm{FVC} \text {. There was a significant inverse } \\
\text { correlation for the entire group between } \mathrm{VC}-\mathrm{FVC} \\
\text { and peak VO } 22 / \mathrm{kg}(\mathrm{p}<0.001)\end{array}$ & $\begin{array}{l}\text { The difference between VC and FVC, } \\
\text { measured by spirometry can be used as } \\
\text { an index of severity of airflow limitation } \\
\text { and to predict exercise performance in } \\
\text { COPD patients }\end{array}$ \\
\hline $\begin{array}{l}\text {-Martinez et al/20195 } \\
24 \text { COPD patients }(12 \\
\text { males) }\end{array}$ & $\begin{array}{l}18 \text { individuals }(75 \%) \text { presented DH. There was } \\
\text { significant difference when comparing IC } \\
\text { measured at rest with the other serial IC } \\
\text { measurements }(\mathrm{p}<0.0001)\end{array}$ & $\begin{array}{l}\text { The SVCFVC difference presented a } \\
\text { weak correlation with the development } \\
\text { of DH during the } 6 \mathrm{MWT} \text { in patients } \\
\text { with COPD }\end{array}$ \\
\hline $\begin{array}{l}\text {-Saravanan et } \\
\text { al/2018 } \\
\text { prospective cross- } \\
\text { sectional study } \\
\text {-353 Obstructive lung } \\
\text { disease patients }\end{array}$ & $\begin{array}{l}\mathrm{FEV}_{1} / \mathrm{FVC} \text { revealed the presence of airway } \\
\text { obstruction in } 131(37 \%) \text { individuals compared to } \\
165(46 \%) \text { individuals by } \mathrm{FEV}_{1} / \mathrm{SVC} \text { ratio. In the } \\
\text { obstruction and mixed groups, the difference in } \\
\text { vital capacity } \mathrm{SVC}-\mathrm{FVC} \text { is statistically superior } \\
(\mathrm{p}<0.05) \text { when compared to normal and restriction } \\
\text { groups }\end{array}$ & $\begin{array}{l}\text { The } \mathrm{FEV}_{1} / \mathrm{SVC} \text { ratio detected the } \\
\text { presence of airway obstruction in more } \\
\text { individuals than did } \mathrm{FEV} \mathrm{V}_{1} / \mathrm{FVC} \text { ratio } \\
\text { and hence } \mathrm{FEV} / \mathrm{SVC} \text { is a more reliable } \\
\text { factor in the detection of obstructive } \\
\text { airway diseases }\end{array}$ \\
\hline $\begin{array}{l}\text {-Nathell et al/2007 } \\
\text {-3,887 COPD patients }\end{array}$ & $\begin{array}{l}10.2 \% \text { fulfilled the NICE COPD-criteria, } 14.0 \% \\
\text { the GOLD COPD-criteria and } 21.7 \% \text { the ERS } \\
\text { COPD criteria. The diagnosis according to NICE } \\
\text { and GOLD guidelines is based on FVC and ERS } \\
\text { guidelines is based on the best value of SVC or } \\
\text { FVC }\end{array}$ & $\begin{array}{l}\text { Substantially more subjects with COPD } \\
\text { were found when the best of either SVC } \\
\text { or FVC was used. FVC was higher than } \\
\text { SVC when lung function was normal } \\
\text { and in those with mild obstruction prior } \\
\text { to bronchodilation whereas SVC was } \\
\text { more than FVC after bronchodilation in } \\
\text { severe airway obstruction }\end{array}$ \\
\hline
\end{tabular}

NHANES III-National health and nutrition examination survey III, EVC-Expiratory vital capacity, VC-Vital capacity, COPD-Chronic obstructive pulmonary disease, 6 MWT-6-minute walking test, DH-dynamic hyperinflation, BOS-Bronchiolitis obliterans syndrome, SVC-Slow vital capacity, FVC-Forced vital capacity, FEF-Forced expiratory flow, FEV 1 -Forced expiratory volume in 1 second.

\section{CONCLUSION}

Slow vital capacity is a comfortable and convenient maneuver and it should be routinely performed as part of pulmonary function test in clinical practice. It is most helpful in symptomatic subjects particularly with preserved $\mathrm{FEV}_{1} / \mathrm{FVC}$ who are young and obese. As in this set of patients $\mathrm{FEV}_{1} / \mathrm{SVC}$ criteria can uncover cases of obstructive lung disease that are missed by $\mathrm{FEV}_{1} / \mathrm{FVC}$ measurement leading to earlier diagnosis and improved clinical outcomes. The difference between SVC and FVC (SVC-FVC) are greater in patients with airway obstruction. This is possibly because FVC maneuvers are forced maneuvers and can cause small airways collapse therefore leading to underestimation of the vital capacity. However, caution must be exercised in using FEV1/SVC criteria as indicator of underlying obstructive lung condition in elderly population. The FVC decreases with age at a faster rate than SVC and hence a low $\mathrm{FEV}_{1} / \mathrm{SVC}$ ratio might simply reflect the physiological changes of aging in the elderly population. Thus $\mathrm{FEV}_{1} / \mathrm{SVC}$ should be used with caution in elderly subjects (age $>70$ years) with preserved $\mathrm{FEV}_{1} / \mathrm{FVC}$ as a criteria of airway obstruction because a low value may represent a false positive finding for air flow obstruction. The measurement of SVC is also important in the patients with neuromuscular diseases like ALS as it is easy to measure the SVC in these patients and it also, predicts prognosis, survival and functional decline in ALS patients. It is generally seen that most laboratories perform only the FVC maneuver due to time and operational constraints. But if both SVC and FVC maneuvers are performed it will provide better information about the underlying obstructive process to the clinicians.

\section{Funding: No funding sources \\ Conflict of interest: None declared \\ Ethical approval: Not required}

\section{REFERENCES}

1. Pellegrino R, Viegi G, Brusasco V, Crapo RO, Burgos F, Casaburi R et al. Interpretative strategies for lung function tests. Eur Respir J. 2005;26:948-68.

2. Wanger J, Clausen JL, Coates A, Pedersen OF, Brusasco V, Burgos F et al. Standardisation of the measurement of lung volumes. Eur Respir J. 2005;26:511-22.

3. Chhabra SK. Forced vital capacity, slow vital capacity, or inspiratory vital capacity: which is the best measure of vital capacity? J Asthma. 1998;35:361-5.

4. Miller MR, Hankinson J, Brusasco V, Burgos F, Casaburi R, Coates A, et al. Standardisation of spirometry. Eur Respir J. 2005;26:319-38. 
5. Jackson C, De Carvalho M, Genge A, HeimanPatterson T, Shefner JM, Wei J et al. Relationships between slow vital capacity and measures of respiratory function on the ALSFRS-R. Amyotroph Lateral Scler Frontotemporal Degener. 2018;19:50612.

6. Cohen J, Postma DS, Vink-Klooster K, Van der Bij W, Verschuuren E, Ten Hacken NH et al. FVC to slow inspiratory vital capacity ratio: a potential marker for small airways obstruction. Chest. 2007;132:1198203.

7. Barros AR, Pires MB, Raposo NM. Importance of slow vital capacity in the detection of airway obstruction. J Bras Pneumol. 2013;39:317-22.

8. Sahebjami H, Gartside PS. Pulmonary function in obese subjects with a normal $\mathrm{FEV}_{1} / \mathrm{FVC}$ ratio. Chest. 1996;110:1425-9.

9. Saint-Pierre M, Ladha J, Berton DC, Reimao G, Castelli G, Marillier $M$ et al. Is the Slow Vital Capacity Clinically Useful to Uncover Airflow Limitation in Subjects with Preserved $\mathrm{FEV}_{1} / \mathrm{FVC}$ Ratio? Chest. 2019;156(3):497-506.

10. Fortis S, Corazalla EO, Wang Q, Kim HJ. The difference between slow and forced vital capacity increases with increasing body mass index: a paradoxical difference in low and normal body mass indices. Respir Care. 2015;60:113-8.

11. Bubis MJ, Sigurdson M, McCarthy DS, Anthonisen NR. Differences between slow and fast vital capacities in patients with obstructive disease. Chest. 1980;77:626-31.

12. Chan ED, Irvin CG. The detection of collapsible airways contributing to airflow limitation. Chest. 1995; 107:856-9.

13. Berton DC, Neder JA. Measuring slow vital capacity to detect airflow limitation in a woman with dyspnea and a preserved FEV1/FVC ratio. J Bras Pneumol. 2019;45:e20190084.

14. Simonsson BG. Dynamic Spirometry Studies in Patients with Lung Disease. Iii. Comparison between Slow and Forced Vital Capacities. Acta Allergol. 1963;18:353-64.

15. O'Brien C, Guest PJ, Hill SL, Stockley RA. Physiological and radiological characterisation of patients diagnosed with chronic obstructive pulmonary disease in primary care. Thorax. 2000;55:635-42.

16. Huprikar NA, Skabelund AJ, Bedsole VG, Sjulin TJ, Karandikar AV, Aden JK et al. Comparison of the Forced and Slow Vital Capacity Maneuvers in Defining Airway Obstruction. Respir Care. 2019.

17. Lalley PM. The aging respiratory system--pulmonary structure, function and neural control. Respir Physiol Neurobiol. 2013;187:199-210.

18. Pinto S, De Carvalho M. Comparison of slow and forced vital capacities on ability to predict survival in ALS. Amyotroph Lateral Scler Frontotemporal Degener. 2017;18:528-33.
19. Pinto S, De Carvalho M. SVC Is a Marker of Respiratory Decline Function, Similar to FVC, in Patients With ALS. Front Neurol. 2019;10:109.

20. Lechtzin N, Cudkowicz ME, De Carvalho M, Genge A, Hardiman $\mathrm{O}$, Mitsumoto $\mathrm{H}$ et al. Respiratory measures in amyotrophic lateral sclerosis. Amyotroph Lateral Scler Frontotemporal Degener. 2018;19:32130.

21. Pinto S, De Carvalho M. Correlation between Forced Vital Capacity and Slow Vital Capacity for the assessment of respiratory involvement in Amyotrophic Lateral Sclerosis: a prospective study. Amyotroph Lateral Scler Frontotemporal Degener. 2017;18:86-91.

22. Gordon PH. Amyotrophic Lateral Sclerosis: An update for 2013 Clinical Features, Pathophysiology, Management and Therapeutic Trials. Aging Dis. 2013;4:295-310.

23. Pinto S, Carvalho M. Breathing new life into treatment advances for respiratory failure in amyotrophic lateral sclerosis patients. Neurodegener Dis Manag. 2014;4:83-102.

24. Miller RG, Jackson CE, Kasarskis EJ, England JD, Forshew D, Johnston W et al. Practice parameter update: the care of the patient with amyotrophic lateral sclerosis: drug, nutritional, and respiratory therapies (an evidence-based review): report of the Quality Standards Subcommittee of the American Academy of Neurology. Neurology. 2009;73:1218-26.

25. Corcia P, Pradat PF, Salachas F, Bruneteau G, Forestier N, Seilhean D et al. Causes of death in a post-mortem series of ALS patients. Amyotroph Lateral Scler. 2008;9:59-62.

26. De Carvalho M, Matias T, Coelho F, Evangelista T, Pinto A, Luis ML. Motor neuron disease presenting with respiratory failure. J Neurol Sci. 1996;139:11722.

27. Bourke SC, Tomlinson M, Williams TL, Bullock RE, Shaw PJ, Gibson GJ. Effects of non-invasive ventilation on survival and quality of life in patients with amyotrophic lateral sclerosis: a randomised controlled trial. Lancet Neurol. 2006;5:140-7.

28. Miller RG, Rosenberg JA, Gelinas DF, Mitsumoto H, Newman D, Sufit R et al. Practice parameter: the care of the patient with amyotrophic lateral sclerosis (an evidence-based review): report of the Quality Standards Subcommittee of the American Academy of Neurology: ALS Practice Parameters Task Force. Neurol. 1999;52:1311-23.

29. Diagnosis ETFo, Management of Amyotrophic Lateral S, Andersen PM, Abrahams S, Borasio GD, de Carvalho M, et al. EFNS guidelines on the clinical management of amyotrophic lateral sclerosis (MALS)--revised report of an EFNS task force. Eur J Neurol. 2012;19:360-75.

30. Fallat RJ, Jewitt B, Bass M, Kamm B, Norris FH, Jr. Spirometry in amyotrophic lateral sclerosis. Arch Neurol. 1979;36:74-80.

31. Czaplinski A, Yen AA, Appel SH. Forced vital capacity (FVC) as an indicator of survival and disease 
progression in an ALS clinic population. J Neurol Neurosurg Psychiatry. 2006;77:390-2.

32. Pinto S, Turkman A, Pinto A, Swash M, De Carvalho M. Predicting respiratory insufficiency in amyotrophic lateral sclerosis: the role of phrenic nerve studies. Clin Neurophysiol. 2009;120:941-6.

33. Baumann F, Henderson RD, Morrison SC, Brown M, Hutchinson N, Douglas JA et al. Use of respiratory function tests to predict survival in amyotrophic lateral sclerosis. Amyotroph Lateral Scler. 2010;11:194-202.

34. Ringel SP, Murphy JR, Alderson MK, Bryan W, England JD, Miller RG et al. The natural history of amyotrophic lateral sclerosis. Neurol. 1993;43:131622.

35. Lechtzin N, Wiener CM, Shade DM, Clawson L, Diette GB. Spirometry in the supine position improves the detection of diaphragmatic weakness in patients with amyotrophic lateral sclerosis. Chest. 2002;121:436-42.

36. Schiffman PL, Belsh JM. Pulmonary function at diagnosis of amyotrophic lateral sclerosis. Rate of deterioration. Chest. 1993;103:508-13.

37. Andrews JA, Meng L, Kulke SF, Rudnicki SA, Wolff AA, Bozik ME et al. Association Between Decline in Slow Vital Capacity and Respiratory Insufficiency, Use of Assisted Ventilation, Tracheostomy, or Death in Patients with Amyotrophic Lateral Sclerosis. JAMA Neurol. 2018;75:58-64.

38. Paillisse C, Lacomblez L, Dib M, Bensimon G, Garcia-Acosta S, Meininger V. Prognostic factors for survival in amyotrophic lateral sclerosis patients treated with riluzole. Amyotroph Lateral Scler Other Motor Neuron Disord. 2005;6:37-44.

39. Gil J, Preux PM, Alioum A, Ketzoian C, Desport JC, Druet-Cabanac $\mathrm{M}$ et al. Disease progression and survival in ALS: first multi-state model approach. Amyotroph Lateral Scler. 2007;8:224-9.

40. Chrismer I, Witherspoon J, Drinkard B, Stockman M, Shelton M, Kuo A et al. P.54 Forced and slow vital capacities in RYR1-RM. Neuromuscular Disorders. 2018;28:S47.

41. Janssens JP, Pache JC, Nicod LP. Physiological changes in respiratory function associated with ageing. Eur Respir J. 1999;13:197-205.
42. Constán EMJ, Silvestre A, Alvarez I, Olivas R. Difference between the slow vital capacity and forced vital capacity: predictor of hyperinflation in patients with airflow obstruction. Internet $\mathbf{J}$ Pulm Med. 2005;4:1.

43. Nesterovska OSG, Stupnytska A. Evaluation of Slow Vital capacity and Forced Vital Capacity in patients with COPD. Eur Respir J. 2018;52:748.

44. Yuan W, He X, Xu QF, Wang HY, Casaburi R. Increased difference between slow and forced vital capacity is associated with reduced exercise tolerance in COPD patients. BMC Pulm Med. 2014;14:16.

45. Wenzel SE, Schwartz LB, Langmack EL, Halliday JL, Trudeau JB, Gibbs RL et al. Evidence that severe asthma can be divided pathologically into two inflammatory subtypes with distinct physiologic and clinical characteristics. Am J Respir Crit Care Med. 1999;160:1001-8.

46. Rasheed AVV, Shahzad S, Arjomand DM, Reminick S. Underdiagnosis of obstructive disease by spirometry. Chest. 2011;140:691.

47. Toren K, Olin AC, Lindberg A, Vikgren J, Schioler L, Brandberg J et al. Vital capacity and COPD: the Swedish CArdioPulmonary bioImage Study (SCAPIS). Int $\mathrm{J}$ Chron Obstruct Pulmon Dis. 2016;11:927-33.

48. Nathell L, Nathell M, Malmberg P, Larsson K. COPD diagnosis related to different guidelines and spirometry techniques. Respir Res. 2007;8:89.

49. Saravanan MRP, Rajarajeswari K. Which is better among FEV1/FVC and FEV1/SVC in obstructive airway disease? Int J Adv Med. 2018;5:1328-30.

50. Martinez L, Rodrigues D, Donaria L, Furlanetto KC, Machado FVC, Schneider LP et al. Difference Between Slow and Forced Vital Capacity and Its Relationship with Dynamic Hyperinflation in Patients with Chronic Obstructive Pulmonary Disease. Lung. 2019;197:9-13.

Cite this article as: Singh $\mathrm{S}$, Khan SZ, Patel B, Gumpeni R, Verma S, Talwar A. Slow vital capacity. Int J Adv Med 2021;8:144-51. 